\title{
Role of Vegetation for the Protection of Phewa Watershed, Kaski, Nepal
}

\author{
Bimal Bahadur Kunwar, ${ }^{1, *}$, Basanta Raj Adhikari ${ }^{2}$, Nantakan Muensit ${ }^{3}$, Kuaanan Techato ${ }^{4}$, \\ Saroj Gyawali ${ }^{5}$

\begin{abstract}
${ }^{1}$ Faculty of Environmental Management, Prince of Songkla University, Songkhla 90112, Thailand ${ }^{2}$ Department of Civil Engineering, Institute of Engineering, Tribhuvan University, Pulchowk Campus, Nepal

${ }^{3}$ Faculty of Science, Prince of Songkla University, Songkhla 90112, Thailand

${ }^{4}$ Faculty of Environmental Management, Prince of Songkla University, Songkhla 90112, Thailand

${ }^{5}$ Sustainable Energy and Research Institute, Kathmandu, Nepal
\end{abstract}

Received December 21, 2021; Revised January 22, 2022; Accepted February 24, 2022

\section{Cite This Paper in the following Citation Styles}

(a): [1] Bimal Bahadur Kunwar, Basanta Raj Adhikari, Nantakan Muensit, Kuaanan Techato, Saroj Gyawali , "Role of Vegetation for the Protection of Phewa Watershed, Kaski, Nepal," Environment and Ecology Research, Vol. 10, No. 2, pp. 161 - 173, 2022. DOI: 10.13189/eer.2022.100205.

(b): Bimal Bahadur Kunwar, Basanta Raj Adhikari, Nantakan Muensit, Kuaanan Techato, Saroj Gyawali (2022). Role of Vegetation for the Protection of Phewa Watershed, Kaski, Nepal. Environment and Ecology Research, 10(2), 161 173. DOI: 10.13189/eer.2022.100205.

Copyright $(2022$ by authors, all rights reserved. Authors agree that this article remains permanently open access under the terms of the Creative Commons Attribution License 4.0 International License

\begin{abstract}
Natural resources as well as watersheds are vulnerable all over the world by a variety of natural and anthropogenic activities. Mountain watersheds in the Nepal Himalaya are severely degraded due to active tectonics and Asian Monsoon. The Phewa watershed is one of the vulnerable watersheds in this region, which is also included in the Ramsar sites. This watershed has degraded due to soil erosion, weak geology, fragile landscape, encroachment and climate change. Therefore, this research focuses on the status of the watershed and the role of vegetation for preserving it from further degradation. Protecting and conserving water, vegetation, and soil, as well as reforesting, have been the most common means of preventing watershed risks. Vegetation can help with slope stability, velocity reduction of water, and surface roughness, as well as soil infiltration, better soil structure, and increased soil strength. Species that are native to the area offer superior erosion control because of their fast growing properties and the ability to reproduce quickly, which are important for the watershed's protection.
\end{abstract}

Keywords Eutrophication, Soil Erosion, Sedimentation, Invasive Species, Ecological

\section{Introduction}

A watershed is a section of a land that drains precipitation into a single point, typically the basin's exit, wherein the water can flow into other water bodies as in a river, wetland, lake, reservoir, marsh, sea, or ocean $[1,2]$. It refers to source of water for a particular drainage system. According to the DFRS [3], a total of 690 watersheds covering $147181 \mathrm{sq} \mathrm{km}$ were created across Nepal. Out of 690, 88 watersheds are located in the Gandaki Province, Nepal. There are 10 Ramsar sites in Nepal, one of which being the Lake Cluster of Pokhara Valley including the Phewa Watershed. In 2016, the site was declared to safeguard regional biodiversity and preserve natural resources for tourism. The Phewa watershed extends from $83^{\circ} 48^{\prime} 1.93^{\prime \prime}$ to $83^{0} 58^{\prime} 13.18^{\prime \prime}$ east and $28^{0} 11^{\prime} 37.83^{\prime \prime}$ to $28^{0} 17^{\prime} 27.30^{\prime \prime}$ north (Fig. 1). It is located in the humid subtropical climate with an average rainfall of $3,710 \mathrm{~mm}$ [4]. With a population of 65,256 [5], the watershed is located in Nepal's mid-hill zone and includes Pokhara Metropolitan City wards 2, 4, 5, 6, 7, 8, 19, 22, 23, 24, and Annapurna Rural Municipality wards 1, 2, 3 and 4. This watershed is developed between 25 and 65 million years ago, during the Tertiary Period [6]. The watershed area constitutes a unique geographical entity and exhibits the usual traits of the highland environment with a wonderful 
panoramic perspective of temperate High Peak in the north and humid warm climate of Terai in a conical peculiar valley landscape of mid-hill Pokhara. The altitude ranges from 793 meters to 2508.81 meters. The watershed is in a vulnerable physiographic zone that receives substantial monsoon rainfall. The watershed region is made up of $44 \%$ woodland, 39\% agricultural areas, 5\% residential and marshland area, 5\% grass and barren land, $4 \%$ lake, and $3 \%$ shrub area [7]. Bhandari et al. (8) compiled a checklist of flowering plants in this region, documenting 613 species from 111 families. Similarly, Tamrakar [9] explored 60 aquatic plant species, 203 terrestrial plant species, 28 fish species, 11 frog species, 28 reptile species, and 36 mammals on the Pokhara Lake clusters including the common otter, which is listed on Appendix I of the CITES. Ten of the 168 bird species are listed in the CITES Appendix, while five are listed in the IUCN's various threat categories.

Due to geological and climatic circumstances, the watershed is particularly prone to rainfall induced landslides. Watershed ecosystems are typically stable and sturdy. Because of the naturally weak geological characteristics of rocks and soils, the Himalaya is an extremely fragile mountain [10]. Due to periodic monsoon rains and intense yet inefficient land use methods for farming and development, the Phewa watershed is one of Nepal's most unstable ecosystems. Each of Nepal's physiographic zones is very dangerous due to the country's high peaks, steep slopes, weak rock, and heavy soil cover over intact bed rock, as well as the monsoon climate. Larger wetlands are uncommon in the region due to the region's mountainous physiography [11]. Watershed management is the process of implementing strategies, programs, and initiatives to maintain and improve watershed roles in regulating flora, fauna, and human populations within the boundaries of a watershed to ensure the sustainability of the watershed [12]. Watershed management began with the primary goal of avoiding erosion, floods, and maintaining the long-term durability of useable water supplies [13]. Catchments are always changing and these changes must be factored into management. Since the twentieth century, however, unsustainable development has presented a danger to the ecology of watersheds in many parts of the world. Slope failures, erosion, floods, ecological imbalance, and excessive water extraction and agricultural activities all contribute to the degradation of the watershed. Particularly, the Phewa-lake has changed from oligotrophic to mesotrophic to eutrophic throughout the 1970s, 1980s, and 1990s [6]. Phewa Lake has a water surface size of 1.793 Square Kilometer and a maximum depth of 23 meters [14]. Even though biodiversity threats are a critical concern, watershed management has paid little attention to them.

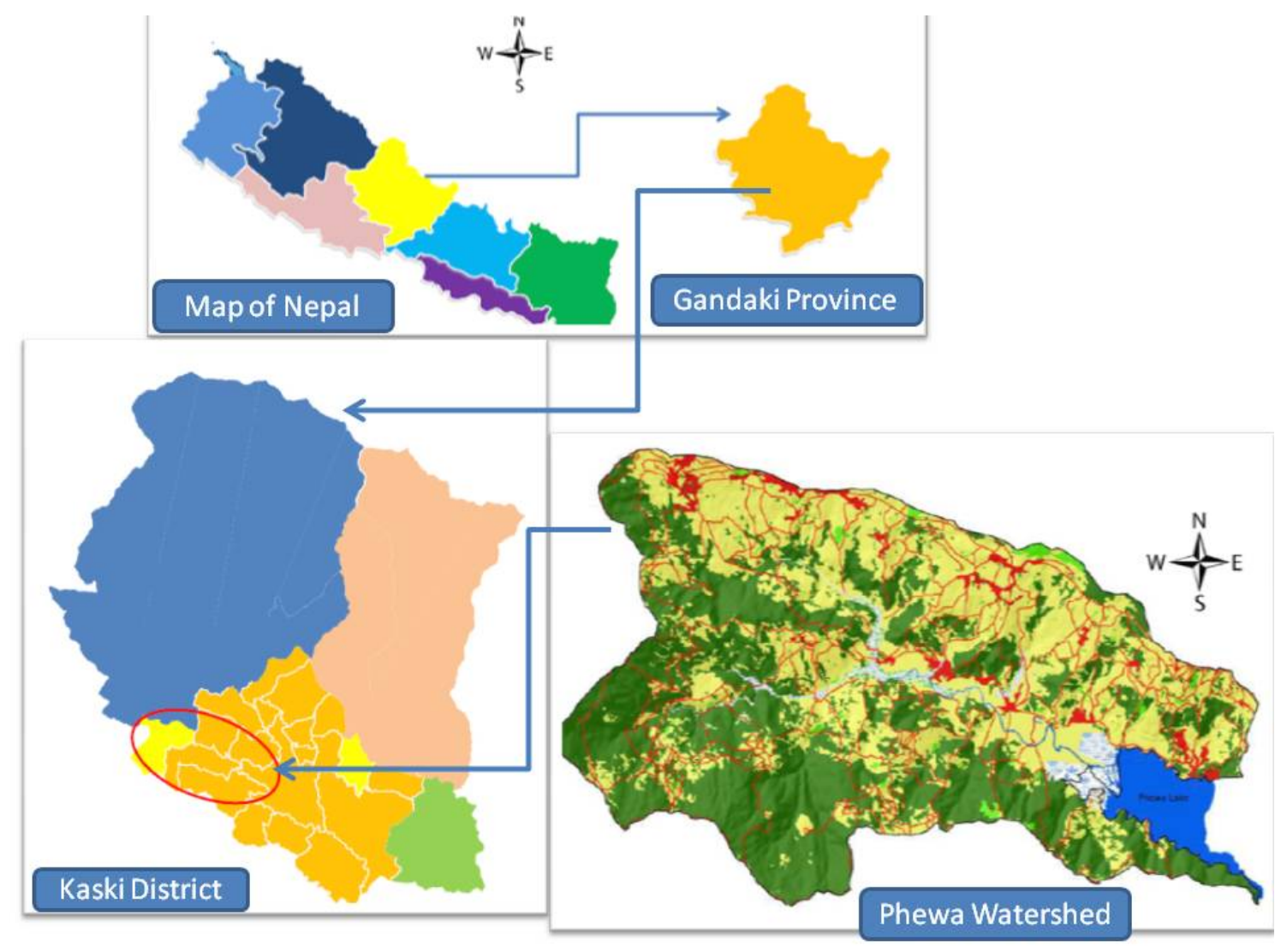

Figure 1. Study area 
Therefore, this study aims to analyze the condition of the Phewa Watershed. The study then focuses on identifying potential explanatory variables such as soil erosion, landslides, sedimentation, and plant invasion, as well as how to manage them utilizing vegetation. The Phewa Watershed is under threat from a multitude of factors, including landslides, soil erosion, eutrophication, alien species, road construction, and encroachment, according to the research premise.

\section{Methodology}

This study focuses on the biodiversity threat, watershed, Phewa Lake, watershed management, and plant cover from the information available in the scientific journals, academic publications, conference papers, textbooks, and unpublished reports. Altogether, 113 articles focused on vegetation as a threatened mitigation measures from journals, academic publications, conference papers, textbooks, and internet assets (see Table 1) are used for this study. This study mainly focused on the threats to the Phewa watershed and possible mitigation measure using vegetation to protect it from future deterioration.

Table 1. Literature reviews list

\begin{tabular}{|c|c|c|}
\hline SN & Type & Number \\
\hline 1 & Scientific Journals & 50 \\
\hline 2. & Book Chapter & 22 \\
\hline 3 & Reports & 26 \\
\hline 4 & News paper & 2 \\
\hline 5 & Thesis & 3 \\
\hline 6 & Conference/proceeding Paper & 8 \\
\hline 7 & e-portal & 2 \\
\hline
\end{tabular}

\section{Existing Problems}

\subsection{Threat}

Natural resources are under jeopardy all around the globe. According to Millennium Ecosystem Assessment [15], just four ecosystem services have improved in the last 50 years, fifteen are in significant decline, and five are stable in general but under threat in specific regions of the world. Land degradation is a global problem that affects over 8 million Square Kilometer of land and threatens the livelihoods of over 1 billion people [16]. Despite the fact that watersheds are endangered by a range of natural sources, the majority of the problems stem from direct or indirect human involvement with them. As a sociopolitical-ecological entity, the watershed is vital in providing dietary, societal, and income security, along with critical life support services to assist stakeholder activities in the catchment [2]. The interaction of physical, biophysical, and human activities in Himalayan watersheds has resulted in a complex physiography. Due to geological and climatic factors, as well as extensive but inefficient land use methods for farming and habitation, the Nepalese Himalayas are one of the world's most vulnerable ecosystems. According to [17], severely degraded watersheds cover around $10 \%$ of Nepal's area whereas extremely good condition watersheds cover just $33 \%$ of the territory. The majority is defined by steep hills, large height differences over short distances, scarring river and stream banks from landslides and gullies, massive rocks in limited watercourses from massive dumping and floods, sparse vegetation, farmlands, and dispersed human settlement. The watershed is threatened by encroachment, eutrophication, landslides and sedimentation, invasive species; toxic pollution, overfishing, water diversion, acidification, and climate change [18]. Flowing processes and complicated interactions develop throughout valleys as a result of natural dams created by landslides or debris-laden flows caused by streams, culminating in the formation of lakes [19]. It indicates that the watershed region is vulnerable to soil erosion and landslides due to its current conditions. According to the Ministry of the Environment, the Kaski district is severely vulnerable to landslides [20]. The Phewa watershed is one of the most susceptible due to folded, faulted and fractured meta-sedimentary rocks [21]).

According to aerial images and field observations in 1977, approximately half of the area in the Phewa watershed was in terrace, $28 \%$ unmanaged forest, $11 \%$ grassland and pastureland, 7\% deteriorated scrub and 1\% gullies or slides [22]. According to Poudel and Mandal [23], degraded land occupies 0.3 percent of the Phewa watershed, whereas forest, agricultural, built-up, and water bodies cover 52.98 percent, 27.90 percent, 16.40 percent, and 2.40 percent, respectively. Although forest cover benefits both physical and environmental elements, soil erosion and sedimentation are the most pressing challenges in the Phewa watershed. The Phewa watershed is commonly endangered by landslides, soil erosion, exotic species invasion, climate change and pollution, and upstream and downstream sedimentation (Fig. 2). The fundamental sources of debris and slides include the thermoplastic phenomena as well as external environmental variables such as climate, soil type, earthquake frequency, road construction and slope. As a result of nutrient loading from agriculture, landslides and increased development in the surrounding region, the lake is mesotrophic and presently experiencing serious environmental difficulties [24]. In 2014 and 2015, the average sediment flux of Phewa Lake was 16 and 17 tons per acre per year, respectively [25]. Rapid eutrophication is increasingly prevalent $[4,26]$ and the lake is also seasonally oligotrophic as a result of high rainfall in its catchment area [27]. Extreme lake-area encroachment, increased eutrophication, invasive species, water diversion, toxic contamination, acidification, unregulated fishing, sedimentation, hotel water pollution 
and the effects of extreme weather occurrences are just a few of the major threats to Phewa Lake [26]. The introduction of non-native plants into the wetland, the removal of buffering vegetation, and upland forest deterioration are the main causes of vegetation loss [28]. According to Friedrichsen [29], urbanization may be the most serious long-term threat to watersheds because the eastern and northern parts of the Phewa watershed are rapidly developing and encroaching on metropolitan centers.

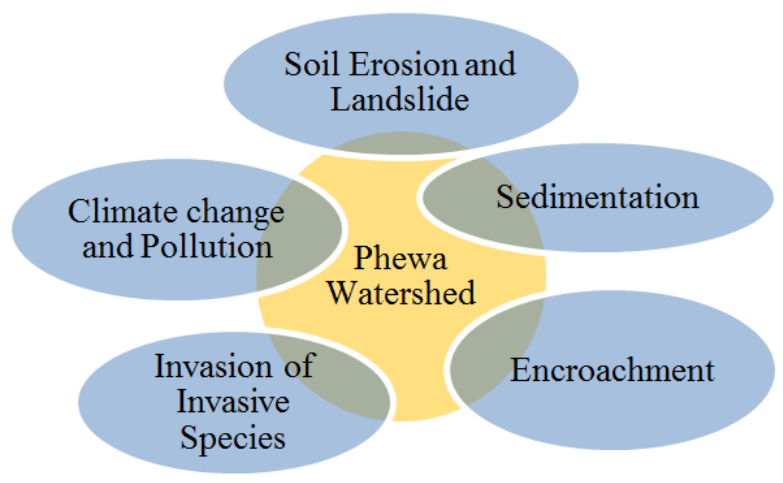

Figure 2. Threatened of Phewa watershed

\subsection{Soil Erosion and Landslide}

Landslides, surface runoff, floods, ecological imbalance, and excessive water collection for farming activities are the primary causes of watershed damage [30]. Individual soil particles split from the soil mass are moved by erosive agents such as flowing water and wind and these sediments are deposited to the river bed. Globally, the leading causes of soil degradation are deforestation and loss of natural vegetation (43\%), overgrazing (29\%), insufficient farming practices $(24 \%)$, and overexploitation of natural vegetation (4\%) [31]. Abandoned terraces are more prone to erosion as a result of labor migration from the highlands to urban areas [32]. Because of heavy land use without appropriate consideration of conservation measures coupled with excessive rainfall, the erosion process in the watershed has transported a large amount of silt to the lake diminishing its capacity [33]. Water erosion itself has destroyed 1094 million hectares of land globally, with 751 million hectares severely impacted $[34,35]$ and 3 million hectares of agricultural land lost per year due to erosion $[34,35,36]$. Himalayan countries are particularly prone to soil erosion due to their steep topography and thin soil thickness [37]. The intensive rainfall mostly dominates the soil erosion in the Asian highland [38]. The ultimate impacts of watershed degradation, such as soil erosion, landslides, high sedimentation, water pollution, floods and droughts, must be detected as soon as feasible in order to protect watersheds. Anthropogenic (indiscriminate deforestation, road construction, mining, poorly regulated diversion, logging, and improper farming) and natural (landslides, wildfires, and floods) elements may emerge at any time and degrade the landscape in future.
Increased soil erosion deteriorates the watershed's ecosystem by causing sedimentation, deteriorating water supplies, diminishing forest production and compromising other vital environmental services [39]. Landslides are characterized as processes that cause the downward and outward movement of slope-forming substances composed of natural rocks, soil, manmade fill, or mixes of these elements [40, 41]. Between 2004 and 2010, landslides killed around 4500 people worldwide (excluding seismically caused landslides) [42]. The most human lives are lost in India, China, the Philippines, and Nepal, with landslides wreaking havoc on populations and infrastructure [43]. A total number of landslides were found to be 4351 causing 5437 of recorded death tools from 1971to 2019 [44, 45] in Nepal. These numbers of landslides and death tolls are different in different physiographic regions due to the variation of geomorphology and microclimate [46].

The maximum and lowest mean monsoon rainfalls are $1,236 \mathrm{~mm}$ and $506 \mathrm{~mm}$, respectively [47]. According to an IPCC report [48], meteorological factors will alter due to climate change in future directly contributing landslide generation. There is also a correlation between rainfall intensity, rainfall duration and landslide incidents [49]. This rainfall acts differently in different slope gradients. Around 10 percent of the watershed is plain to rising ( $0-10 \%$ gradient), 60 percent has slopes ranging from $20 \%$ to $60 \%$, and 15 percent is exceptionally sharp $(60-100 \%$ gradient) $[22,27]$ in this watershed. Basnet et al. [50] explained that the landside density is 0.44 per $\mathrm{km}^{2}$. The gradients of the watershed to the south are softer (approximately 30 to 50\%) than those to the north (above $50 \%$ ). The soils in the Phewa watershed area are generally well drained and have a high surface erosion potential, which can lead to gullies and, as a result, landslides [51]. The hill system is broken through by a series of irregular ridges and elevations. Furthermore, anthropogenic activities such as unplanned rural road construction in this watershed has been contributing for increasing soil erosion and land sliding, that has resulted sedimentation in the Phewa lake [52, 53]. Upslope, shallow landslides and soil loss can result in substantial sediment outputs, which can contribute to downstream issues including reservoir sedimentation and pollution. Rapid bedrock uplift and river incision rates are induced by tectonic and climatic forces, earthquakes, increasing precipitation [54].

Soil erosion is prevalent over two-thirds of the area in the Phewa lake watershed with an annual average erosion rate of $29.3(\mathrm{t} / \mathrm{ha} / \mathrm{yr})$ as per 2007 and reduced to 25.4 $(\mathrm{t} / \mathrm{ha} / \mathrm{yr})$ in 2017 [55]. According to CBS [56], protected pasture of Phewa watershed had 920 ton/sq $\mathrm{km} / \mathrm{yr}$ soil erosion, overgrazed grass land had 2200-34700, and gullied overgrazed grass land had 2900 ton/sq.km/yr soil erosion. According to Fleming [57], the soil erosion rate threshold for Nepal is 10-20 tons per hectare per year. This process clogs the rivulets and streams causing major landslides. The vegetation in the watershed slopes protects 
against rainfall-induced erosion; however, the rate of soil losses incurred by sheet and rill erosion on farmland and barren land is relatively high. The aforementioned condition is discreetly available where $39 \%$ agriculture land, $5 \%$ barren land and nearly $40 \%$ sloppy areas occupy the whole watershed [7, 22]. Abandoned agricultural land due to population shifts in the upper levels of the watershed [5] is causing the creation of gullies, which eventually results in soil erosion and landslides.

\subsection{Sedimentation}

The watershed consists of 19 sub-watersheds and the Firke Khola and Seti canal drain the water to the Phewa Lake where the Harpan Khola accounts for $70 \%$ of the total water intake. The Harpan Khola has mean flows of $5.58 \mathrm{~m}^{3} / \mathrm{second}$ [58]. The tributaries or seasonal streams of the Harpan Khola are Hadi, Khahare, Lauruk, Thotne, Thado, Betani, Bhakunde, Faure, Kutuje, Orlan, Kamni, and Turung kholas (khola means small rivers in Nepali). The rainfall fluctuates over the years but the rainy season i.e. June to September accounts 80 percent of yearly rainfall. This flow has frequently been unable to be retained by the watershed due to different pre-disposing conditions. Therefore, this runoff triggers the soil erosion and deposits the sediments to the lake. The yearly sediment deposit at Phewa Lake is $175,000-225,000 \mathrm{~m}^{3}$ [59], which is consistent with Laban's [60] finding that sedimentation rates in highly damaged mountain slopes vary from $16800 \mathrm{~m}^{3} / \mathrm{km}^{2} /$ year to $368 \mathrm{~m}^{3} / \mathrm{km}^{2} /$ year in protected meadows. If this pace of sedimentation is continues, the lake will be gone in $135-175$ years, presuming 80 percent loss of water content. In the last five decades, siltation has reduced the size of Phewa by more than half [61]. Watson et al. [62] estimate that the lake will lose $80 \%$ of its storage capacity in the next 110-347 years based on the pace of areal decline and sediment intake. According to CBS [56], the Phewa watershed has a sediment production of 8.9 tons per hectare per year.

\subsection{Invasion of Invasive Species}

Despite its small size, Nepal is abundant in flowering plants. Nepal is home to 6,973 Angiosperm species, 26 Gymnosperm species, 534 Pteridophytes species, 1,150 Bryophytes species, 1001 Algae species, 1822 Fungi species, and 465 Lichen species, with 284 blooming as endemic plants [63]. In Nepal, there are 25 invasive and alien plant species classified into 13 families [64], while at least 219 alien flowering plant species are becoming natural $[65,66]$. Since the Annanpurna region is intimately related with the Phewa watershed and is heavily influenced by high rainfall, broad leaf species predominate as vegetation in this region [67]. In the Panchase forest, which encompasses the Phewa watershed, there are Schima wallichii-Castanopsis indica, hill sal forests, pine forests, Quercus semicarpifolia-Quercus lamellosa-Rhododendron arboretum, and Daphniphylum himalense forests [63]. Furthermore, the Panchase forest is home to rare, threatened, and unique plant species, including six endemic and three threatened orchid species $[68,69,70,71]$.

The introduction of invasive species is a growing problem in this watershed. The invasive plants such as Eichhornia, Eupatorium, Ageratum species threaten the quality of the watershed. Invasive species are actively invading, creating a danger to increasing agricultural operations, forest, culture, transportation, trade, power production, recreation, and fisheries by eradicating and substituting native biodiversity. Due to sedimentation caused by soil erosion, landslides, and significant water hyacinth invasion, the lake and its watershed have been under intense and exhausting pressure for the last several decades [26]. The loss of aquatic biodiversity has been exacerbated by the challenges posed by invasion like water hyacinth, and the similar situation exists in terrestrial plants due to Ageratum and Eupatorium species. According to Pathak et al. [72], invasive species at Phewa Lake are Alternanthera philoxeroides, Eichhornia crassipes, Ipomoea carnea ssp. Fistulosa, Leersia hexandra, and Pistia stratiotes. Similarly, Acharya [73] reported water hyacinth, parthenium, morning glory and lantana camera on this watershed. All of these aforementioned non-native species, Eichhornia crassipes, are classified as a highly aggressive and troublesome foreign species in the Phewa watershed [74]. Nine of the 14 worst species were found in former Bhadaure Tamagi VDC of Phewa watershed, Parthenium with Ageratum and Ageratina species being the most troublesome [75]. Abandoned agricultural land as a result of population shifts is allowing non-native species to thrive at the watershed. Salinity, nutrients, disturbance, temperature, competition from other associated plants, and natural enemies appear to be the major elements that limit water hyacinth infestations [76]. It was believed that the threat of invasive species would be much lower in natural habitats as compared to disturbed habitats. A pH of 6 to 8 [77] and a temperature of 28 to 30 degrees Celsius are ideal for the growth of water hyacinth [78]. The Phewa Lake has circum-neutral $\mathrm{pH}(6.83 \pm 0.76)$ [79] and the annual water temperature ranges from $15^{\circ}$ to $30^{\circ} \mathrm{C}$ [62]. This invasive species thrives due to upstream soil erosion and sedimentation as well as a lack of natural enemies and an allelopathic impact to compete with other plants. Plant invasions alter the soil microbial community, soil physicochemical characteristics and litter decomposition rates. These activities boost the nitrogen cycle and releasing extra nitrous oxide $\left(\mathrm{N}_{2} \mathrm{O}\right)$ into the atmosphere, fostering global warming and affecting in the geographic ranges of some invasive species [80].

\subsection{Climate Change and Pollution}

The average maximum and lowest temperature trends grew by 0.008 and 0.026 degrees each year, respectively. Furthermore, the average total annual precipitation from 
1980 to 2016 was $3863.29 \mathrm{~mm}$, with July receiving the most precipitation and December receiving the least [73]. Over the previous 30 years (1981-2011), the maximum and lowest average temperatures in the Phewa watershed have risen by $0.81^{\circ} \mathrm{C}$ and $0.2^{\circ} \mathrm{C}$, respectively [47]. Kaski district has a moderate vulnerability rating (i.e. $0.356-0.600$ ) [20]. Phewa Lake is subjected to non-climatic stresses such as pollution [81], $310 \mathrm{Km}$ poorly constructed roads [52], and a variety of local development and human settlements [58]. Traditional farming practices are used by the majority of farmers in watershed areas to cultivate agronomical, legume, spice, vegetable, and fruit crops. The key concerns are the tiny size of land without irrigation infrastructure, the large distance between irrigated land and residential areas, and the soil's high acidity. The effect of climate change in the Himalayas is enormous because it is projected that the temperature will increase at least $1-2{ }^{\circ} \mathrm{C}$ degree centigrade by 2050 [82].

\subsection{Land Encroachment}

The storage capacity of the lake was increased in the early 1960s when a dam was built at the Pardi outlet [47]. In 1975, a structural breakdown ruined the dam forcing it to be reconstructed. After the dam failed, exposing land near the lake, landlords used political and other influence to have the land recorded in their names. The likelihood of encroachment for built-up purposes on 33.79 ha of barren land near Phewa Lake is 33.79 percent [23]. The analysis demonstrates that the forest area, shrub-land, grassland, and built-up area in the watershed were increased whereas agricultural land, surface area of the lake, and barren land were decreased [83].

\section{Watershed Management}

A watershed offers ecological services and water supplies to flora and fauna, as well as agricultural and cultivation activities. Water strength, water capture, and water release are the three fundamental functions of a watershed [84]. EPA [85] estimates that clean and healthy watersheds are responsible for more than $\$ 450$ billion in food, manufactured goods, fiber, and tourism. Micro level precise mapping on the surface of characteristics like surface morphometry, land use, land cover resources, and population parameters is typically a huge difficulty in mountain geography but it is required for watershed management [30]. Sustainable human activities are essential to the ecological balance of watersheds. The water, biota, surrounding watershed, and atmosphere are all interrelated components of the ecosystem; humans are regarded an intrinsic element of this system [86].

To manage vulnerable watersheds, strict adherences to national legislation including the utilization of vegetation on an as-needed basis are required (Fig. 3).

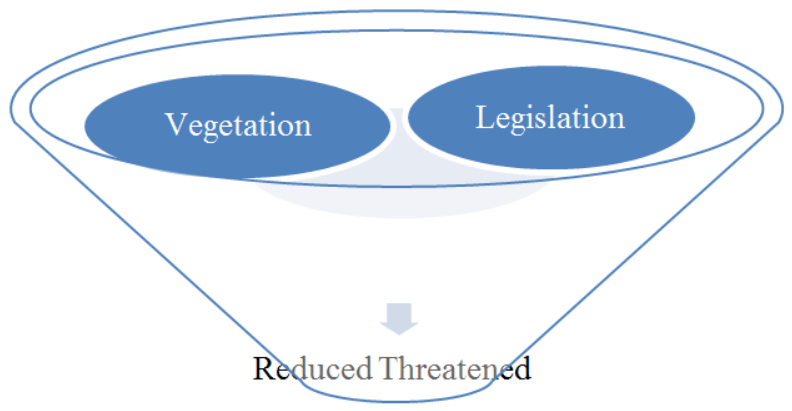

Figure 3. Management of threatened

Watershed management in Nepal is governed by laws such as the Soil and Watershed Conservation Act of 1982, the Land Act of 1964, the National Parks and Wildlife Conservation Act of 1973, the Environmental Protection Act of 1996, the Forest Act of 1993, the Water Resource Act of 1992, and the Local Self-Government Act of 1999. The Soil and Watershed Conservation Act of 2039 (1982) defines how to safeguard or save any place from being devastated by natural catastrophes like as flood, soil-erosion, and landslide, as well as how to maintain cleanliness by preventing muddy water flow. Later in 1985, the Conservation Act was followed by the Soil and Watershed Conservation Regulation provides the government the authority to designate any watershed as a "Protected Watershed" and to introduce improvement conservation initiatives in these areas. The Solid Waste Management and Resource Mobilization Center Act of 1987 established a center as the solid waste management regulatory body. The act is concerned with the pollution of water caused by solid waste. The Water Resources Act of 1992 regulates the use of water; water contamination is prohibited and that governs water resource management as a whole. The Forest Act of 1993 stipulated that trees cannot be destroyed in a manner that has a significant negative impact on the environment, causes public harm or loss, or causes soil erosion in the watershed region. The Water Resource Regulation 1993 (2050 BS) oversees water resource management. The Environment Protection Regulation of 1997 (2054 BS) has a list of water-related projects that require an Environmental Impact Assessment (EIA) or Initial Environmental Examination (IEE). The Local Self-Government Regulation of 1999 established the authorities, functions, and responsibilities of the Village, Municipality, and District Development Centre in the area of water and sanitation. When using water for irrigation from any river/rivulet, the Irrigation Regulations 1999 (2056 BS) mandates that only the leftover water be utilized for irrigation after determining that it will not impair local biodiversity. According to the National Wetland Policy of 2003, wetlands are permanent water basins that receive water from underground sources or precipitation. The Nepal National Water Plan, 2005 and Water Resource Strategy, 2002 include management of ecosystem and develop action plans for water-induced tragedies, an environmental plan of action for watersheds and water 
ecosystems, water delivery, and sanitation. The Nepalese Constitution of 2015 (2072 BS) governs the country and includes provisions for natural resource protection, management, and use regulations, as well as rights to a healthy environment.

The Ninth Plan placed a strong emphasis on managing water flow by building reservoirs, in order to reduce flood damage and maximize the benefits of water resources [87]. Integrated watershed management activities are given top attention. Priority is given to comprehensive watershed management to protect underground water and soil in the Chure-Bhawar and Terai areas in the Tenth Five Year Plan (2002-2007). Despite the fact that the plan only addresses the Chure Hills and Terai, it strongly advocates for an integrated watershed management strategy. Several watershed management initiatives, including landslide danger zone repair, river training works, eco-zoning-based land use planning along the Lake Coast, and solid waste management, were completed in the Phewa watershed [88] The traditional maintenance of Nepal's watersheds included the creation of terraced areas for crop cultivation. In 1974, Nepal formed the Department of Soil Conservation and Watershed Management, which marked the beginning of systematic watershed management in the country. For three years (1975-1977), the Nepal Government operated the first effort focusing on integrated water catchment management in the Phewa watershed [56] A collaborative and integrated strategy to watershed management was formed in the second half of the 1990s. This includes boosting livelihoods and human development at the farm household, local, or watershed level through the use and conservation of land, water, and forest resources [89].

The best safeguard against extreme weather is a healthy watershed. Watersheds are useful units for natural resource management due to their diverse biophysical and, in most cases, socioeconomic characteristics. According to the 2011 national census, the watershed region of Nepal is home to approximately 590,000 people. It is necessary to maintain a balance between economic development and land and water resource conservation. During a drought, vegetation can hold water, lowering the risk of fire and giving wildlife habitat, and it can also seek out extra water during heavy rains, minimizing erosion and runoff. The most typical ways to prevent watershed threats have been reforestation and displacement of local populations from important places such as steep slopes, forest and wetlands. Increased usage of trees and shrubs can collect and slow down water runoff by $10 \%$ to $20 \%$, allowing water to be conserved before it reaches streams, rivers, and lakes [90]. This method also helps to reduce soil erosion, landslide and sedimentation. Grazing control by social fencing and stall feeding was significantly more effective in reducing erosion and increasing grass and fodder leaf output. Over the next three decades, as a result of the national government's policy of delegating forest management to local people in the Phewa watershed, forest productivity doubled and grass and feed output grew fivefold [22].

Several studies explained the role of vegetation in hazardous events such as landslides, rock falls, and debris flows $[91,92,93]$. The soil is protected from the effects of rainfall by natural vegetation and aids in the infiltration and replenishment of underground water sources. Infiltration capacity is reduced when vegetation cover is displaced [94]. The soil is exposed to extreme precipitation due to a lack of natural vegetation resulting in weak structure and enhanced runoff dissociating the soil particles that promotes soil erosion. Litter and plant cover improved downstream flow, velocity reduction, and surface quality encouraging soil absorption through increased macro-pore density as well as improving soil composition by adding nutrients [95]. According to Igwe et al. [96], preserving existing natural vegetation and tree planting where land has been barren just provide required assistance for soil erosion prevention for the preservation of the global ecosystem. In order to increase slope stability, upslope areas of a site or watershed must have long-term control of soil erosion and sediment generation. Maintaining and improving vegetation cover can help with slope stability, sloughing off rain before it infiltrates, directing water away from unstable slopes, and increasing soil strength $[97,98]$. According to Hasnawir et al. [99], deep-rooted, lateral-spreading species have exhibited stronger pull-out resistance and are regarded ideal for erosion control and reducing negative impacts on forest slopes, such as surface erosion and shallow landslides. They discovered that plant morphological variety hampered sediment retention, and that grass barriers were the best at retaining sediment. Indeed, their findings imply that employing native grass species barriers to begin ecological restoration of eroded gullies is the optimal method. The most important component in encouraging short-term sediment deposition and gully stabilization is gully bed vegetation. Topographical impacts are only noticeable in nearly vegetated gullies: in the apparent lack of any ground natural vegetation, naked steep gullies become really efficient soil infiltration pathways, and deposition rate occurs only when the silt mobility gets lower due to a large reduction in nearby gully steep hill [100]. According to Rehman et al. [101], research in Pakistan on the influence of steep slope and vegetation cover on erosion and sediment production in hilly areas, increasing different vegetation results in a considerable reduction in sediment flow.

The chosen plant should have a deep and extensive root system, as well as be hardy, quick-growing, and suckering [102]. To mechanically maintain a gradient Vs a modest landslide, vegetation must pass through the surface morphology that can be close to $2 \mathrm{~m}$ underneath the surface of the ground [103]. Strong roots act as soil nails on slopes. Large trees can serve as a level in high winds, causing them to break or uproot, affecting the mechanical integrity of the slope [104]. According to Istanbulluoglu and Bras [105], plant instability might result in a sharply fragmented topography with substantially lower elevation than 
landscapes originating from stable, uninterrupted vegetation. Once a plant's suitability for a certain habitat has been determined, above and below ground plant attributes should be considered. Fine root density, stem bending stiffness, stem density, erosion control potential, and debris blockage potential are all factors to consider. Vegetation aids with water logging, underlying soil stability, hardness and fertility, and the enhancement of soil microbes. Ground surface protection has been aided by the presence of herbs, shrubs, and perennial plants with a united root system. Additionally, vegetation improves water quality, reduces storm water runoff, improves wildlife and fishery habitat, and inhibits the establishment of noxious weeds.

To avoid erosion and manage water on the hillslopes, most croplands must be converted to a sophisticated system of terraces due to the steep slopes and heavy rainfall. Because of the higher expense and technical difficulties associated with steep terrain, hardware constructions alone are not acceptable. The use of purely vegetative structures to limit erosion in a short period of time may not be effective, hence a combination of structural and vegetative methods is recommended for slope management [106]. Compared to an earth retaining structure or other geological protection systems, vegetation treatment is the most cost effective. When it comes to species selection, the chosen species should have a deep, strong and wide root system, as well as be indigenous, fast-growing, and bushy type. Restoring the most valued plant communities on engineering building sites will also save long-term maintenance costs, reduce erosion and landslide rates, and improve water quality. Reduced landslide risk can benefit downstream by reducing the amount of sediment that reaches rivers, as well as locally by reducing fatalities and infrastructure damage. Because of the weak geology, naturally high levels of erosion, and mass movements, erosion and sedimentation are a top priority, and this area is particularly prone to land management impacts. Species native to the location, with colonial behavior, suited for the site, have a large biological amplitude of adaptability, a dense and deep root system superior erosion control value, excellent root spread and strength, a fast growing nature, and be commercially available or ability to propagate quickly are needed to protect watershed from landslide, soil erosion, sedimentation, invasive species invasion and reduce or adapt climate change.

Land encroachment and solid waste disposal from hotel, domestic uses and agricultural run-off cause severe trouble to the lake. Phewa is the most contaminated lake diseases germ like E. coli readings in the lake ranging from 39 to 123 units per $100 \mathrm{ml}$, despite the fact more than $100 \mathrm{~kg}$ of soaps and detergents from washing activities [58]. Now several governmental policies, laws and legislation are building up.; they are needed to strongly implement to manage the problem of land encroachment and pollutant. According to Bo et al. [107], the types of slopes that are most sensitive to climate change changing vegetation and ground and surface water levels would alter the stability of slopes. To counteract climate change, ecological base adaptation is the best option where vegetation growth is required.

Prevention, eradication, and control are the three main tactics for dealing with invasive species [108]. Local women's groups in the Pokhara valley have used the biomass of E. crassipes to make handcraft items (e.g., pen holders, dust bins, handbags) [109]. Ecosystem-based Adaptation $(\mathrm{EbA})$ is gaining traction as a cost-effective and environmentally benign way to safeguard human and ecological populations against climate change and biological invasion [110]. In Nepal's initial Biodiversity Strategy [111], alien invasive species were recognized as a threat to all biodiversity, but no management strategy was specified. In the second iteration of the National Biodiversity Strategy and Action Plan 2014-2020, the threats posed by alien species to biodiversity in marshes, agricultural, grasslands, and other ecosystems have indeed been adequately recognized [63]. When an invasive species establishes itself in a new area, it can quickly overtake native species, resulting in a monoculture throughout the landscape. The diversity of macro-invertebrates was favorably connected to water hyacinth, however the impact of water hyacinth on hydro power generation is likely to be limited [112]. Water hyacinth has previously been shown to be a promising plant with a wide range of wastewater treatment uses [113]. To avoid invasive species invasion, it is preferable to convert agricultural land to grassland or forest rather than keeping it barren, which indicates by growing vegetation can reduce penetration of some invasive species. Ornamental value, animal fodder, fish feed, fertilizers, biomass energy (Charcoal Briquetting, Bio Gas), raw materials for building, handcraft manufacturing, paper and board, and as a pollution filter are just a few of the possibilities for the invasive plant.

\section{Conclusions and Recommendation}

Soil erosion, landslides, invasion, and sedimentation are the most serious problems in the Phewa watershed. The anthropogenic effect and natural components have had a significant impact on the watershed. As the Ramsar site's indication authority, it is required to state that it is desirable to apply ecological techniques to decrease soil erosion, sedimentation, climate change and invasion of the non-native plants. To safeguard the watershed, species that are adapted for the site, have a superior erosion control value, a fast growing habit, and the ability to propagate quickly are required. Above and below ground plant features should be examined once a plant's suitability for a specific ecosystem has been determined. The soil is protected from the effects of rainfall by natural vegetation. It aids in the absorption and replenishment of underground water and has a significant impact on slope stability. 
Invasive plants such as Eichhornia, Eupatorium, and Ageratum $s p$. pose a serious threat to this watershed and must be managed.

\section{REFERENCES}

[1] NESC. Watershed management: an overview. Pipeline, Vol. 17, No. 4, pp. 1-7, 2006.

[2] Wani S.P. and Garg K.K. Watershed Management Concept and Principles, Patancheru. International Crops Research Institute for the Semi-Arid Tropics (ICRISAT), India, 2011.

[3] DFRS. Forests and Watershed Profile of Local Level (744) Structure of Nepal. Department of Forest Research and Survey (DFRS). Kathmandu, Nepal, 2017.

[4] Oli K.P. Environmental study of Nepal's Begnas and Rupa lakes (Ed.). National Conservation Strategy Implementation Project, Kathmandu, 1996, xxi+156.

[5] CBS. Nepal- National Population and Housing Census 2011. Government of Nepal, National Planning Commision, Central Bureau of Statitistics, Ramshah Path, Thapathali, Kathmandu, 2011. http://old.cbs.gov.np/nada/index.php/ca talog/54.

[6] Shrestha P. and Janauer G.A. Management of aquatic macrophyte resource: A case of Phewa Lake, Nepal. In: P.K. Jha, S.R. Baral, S.B. Karmacharya, H.D. Lekhak, P. Lacoul (Eds.), Environment and Agriculture: Biodiversity, Agriculture and Pollution in South Asia, Ecological Society (ECOS) Nepal, pp. 99-107, 2001.

[7] DSC (Department of Soil Conservation). Sedimentation survey of Phewa Lake. Ministry of Forest and Soil Conservation, Department of Soil Conservation, Kathmandu, 1994.

[8] Bhandari P., Shanta Budhamagar S. and Krishna K. Shrestha K.K. A checklist of flowering plants of Panchase Protected Forest, Kaski district, central Nepal. J. Nat. Hist. Mus. Vol. 30, pp 18 55-84, 2016

[9] Tamrakar R. Status and Biodiversity of Lakes and Ponds of Lekhnath Municipality. Thesis for the partial fulfillment of Bachelors Degree, Institute of Forestry. Pokhara, Nepal, 2008.

[10] Upreti B.N. The Physiographic and Geology of Nepal and their Bearing on the Landslide Problem. In: Tianchi, L., Chalise, S.R., Upreti, B.N. (Eds), Landslide Hazard Mitigation in the Hindu Kush-Himalaya, ICIMOD, Kathmandu, Nepal, 2001.

[11] Manandhar LP. Wetlands Management: Prospects and Constraints. In: Manandhar, L. P. and B. R. Yadav (Eds). Biodiversity Conservation Efforts in Nepal. Special issue published on the occasion of $10^{\text {th }}$ Wildlife Week, 2005. Department of National Parks and Wildlife Conservation, Kathmandu, Nepal, 2005.

[12] State of California. Watershed Program, Accessed 10 July 2012. Available from URL: http://www.conservation.ca.go v/dlrp/wp/Documents/California\%20Watershed\%20Progra m.pdf.
[13] Ozyuvaci N., Ozhan S. and Görcelioðlu E. Integrated Watershed Management for Sustainable Development of Renewable Natural Resources. Paper presented at the $X i$ World Forestry Congress, Antalya, Turkey, 1997.

[14] Lamichhane D.B. Phewa Lake Watershed Area: settlement and environmental Appraisal, K.B. Lamichhane, lakeside, Baidam, Pokhara, Nepal, 2000.

[15] Millennium Ecosystem Assessment. Ecosystems and human well-being: synthesis. Island Press, Washington, D.C., USA, 2005. http://www.maweb.org/documents/docu ment.356.aspx.pdf

[16] ESC. Agriculture, Land and Desertification: Report of the Secretary General. Economic and Social Council: United Nations, 2001.

[17] DSCWM. Watershed condition of the districts of Nepal. Department of Soil Conservation and Watershed Management (DSCWM), Babarmahal, Kathmandu, Nepal, 1983.

[18] Borre L., Barker D.R. and Duker L.E. Institutional arrangements for managing the great lakes of the world: Results of a workshop on implementing the watershed approach. Lakes and Reservoirs: Research \& Management, Vol. 6, No. 3, 199-209, 2001.

[19] Fort M. Extreme rainfall triggered landslides: hydro-geomorphic impacts and induced risks in the Nepal Himalayas. W.A. Lacerda, E.M. Palmeira, A.L. Coelho Netto, M. Ehrlich (Eds.), Extreme Rainfall Induced Landslides, Editora Signer Ltda, Oficina de Textos, Sao Paulo, 2014, pp. 163-181.

[20] NAPA. National adaptation programme of action (NAPA) to climate change. Kathmandu: Ministry of Environment, Government of Nepal, 2010.

[21] Heyojoo B. and Sharma, R.P. Rural road-induced sedimentation: Severity and local perception in the Phewa Watershed, Kaski District, western Nepal. Journal of Nepal Geological Society, Vol. 46, pp. 171-178, 2013.

[22] Fleming B. and Fleming J.P. A watershed conservation success story in Nepal: Land use changes over 30 years. Waterlines, Vol. 28, pp. 29-46, 2009. doi:10.3362/1756-3 488.2009.004

[23] Poudel S. and Mandal R.A. Spatial analysis of Phewa lake watershed of Kaski District, Nepal. Ecologia, Vol. 10, pp. 78-85, 2020. DOI: 10.3923/ecologia.2020.78.85

[24] Gurung T.B., Wagle S.K., Bista J. D., Dhakal R.P., Joshi P.L., Batajoo R., Adhikari P and Rai A.K. Participatory fisheries management for livelihood improvement of fishers in Phewa Lake, Pokhara, Nepal. Himalayan Journal of Sciences, Vol. 3, No. 5, pp. 47-52, 2005. www.himjsci.com

[25] Dhakal S. The Role of Landslide on the Sediment Budget in Upper Phewa Lake Watershed, Western Nepal. Thesis Submitted to the Faculty of Geo-Information and Earth Observation of the University of Twenty in Partial Fulfillment of the Requirement for the Degree of Master of Science in Geo-Information and Earth Observation, 2015.

[26] Rai A. K. Limnological characteristics of subtropical Lakes Phewa, Begnas, and Rupa in Pokhara Valley, Nepal. 
Limnology, Vol. 1, No. 1, pp. 33- 46, 2000. https://doi.org/10.1007/s102010070027

[27] Adhikari S. Key Structural features and water quality functions of Phewa Lake- Wetland for Water Quality. Egerton University, LWM program, 2018.

[28] Kostrzewa J. and Grabowski M. Opportunistic feeding strategy as factor promoting the expansion of racer go by (Neogobius gymnotrachelus Kessler, 1857) in the Vistula basin. Lauterbornia, Vol. 48, pp. 91-100, 2003.

[29] Friedrichsen G. Eel River water quality monitoring project. Final report. Submitted to State Water Quality Control Board, for 205(J) Contract \#5-029-250-2. Humboldt County Resources Conservation District. Eureka, CA, 1998, 76 pp. [924kb].

[30] Poudel K.P. Geography Information Science and Technology building concept in Nepalese perspectives. Kathmandu, Nepal, 2010.

[31] Oldeman L.R., Hakkeling R.T. and Sombroek W.G. World map of the status of human-induced soil degradation. Explanatory Note. Nairobi, Wageningen: UNEP-ISRIC, 1991.

[32] Jaquet S., Kohler T. and Schwilch G. Labour Migration in the Middle Hills of Nepal: Consequences on Land Management Strategies. Sustainability. 11, 1349, 2019. https://doi.org/10.3390/su11051349

[33] Ross J. D. Erosion and Sedimentation in the Phewa Tal Watershed, Middle Mountain Region, Nepal. A thesis submitted to the department of Geography in conformity with requirements for the degree of Master of Science. Ontario, Canada: Queen's University, Kingston, 1998.

[34] Lal R. Soil Carbon Sequestration in China through Agricultural Intensification, and Reforestation of Degraded and Desertified Ecosystems. Land Degradation and Development, Vol. 13, pp. 469-478, 2002.

[35] Pathak P., Wani S.P. and Sudi R. Gully control in SAT watersheds. Global Theme on Agroecosystems Report no. 15. Monograph, International Crops Research Institute for the Semi-Arid Tropics, Patancheru, Andhra Pradesh, India, 2005.

[36] Woreka B.B. Evaluation of soil in Harerge region of Ethiopia using soil loss models, rainfall simulation and field trials. University of Pretoria, 2004. http://hdl.handle.net/ 2263/26929

[37] Harden C. P. Soil erosion and sustainable mountain development. Mountain Research and Development, Vol. 21, pp. 77-83, 2001.

[38] Wischmeier W.H. and Smith D.D. Predicting rainfall erosion losses. Agri. handbook No. 537. U.S. Dep. of Agr., Science and Education Administration. Washington, 1978.

[39] Manashe E. Bio-structural Erosion Control: Incorporating Vegetation in Engineering Designs to Protect Puget Sound Shorelines. A conference paper relating to the Puget Sound/Georgia Basin Ecosystem in Bellevue, WA, presented at Puget Sound Research, 2001.

[40] Sidle R.C. and Ochiai H. Landslides: Processes, prediction, and land use. Water Resources Monogr, 18. American Geophysical Union, Washington, D.C, 2006.
[41] Walker L.R. and Shiels A.B. Landslide ecology. Cambridge University Press, Cambridge, 2013.

[42] Petley D. Global patterns of loss of life from landslides. Geology, Vol. 40, pp. 927-930, 2012.

[43] Stokes A., Douglas G.B., Fourcaud T., et al. Ecological mitigation of hillslope instability: ten key issues facing researchers and practitioners. Plant Soil, Vol. 377, pp. 1-23, 2014. https://doi.org/10.1007/s11104-014-2044-6

[44] Desinventar. Country Profile of Nepal. UNDRR, 2016. https://www.desinventar.net/DesInventar/profiletab.jsp?co untrycode $=$ npl\&continue $=y$

[45] MoHA. Nepal Disaster Risk Reduction Portal, Ministry of Home and Affairs, Kathmandu, Nepal, 2020. http://drrportal.gov.np/

[46] Adhikari B.R., Bingwei T. Spatiotemporal distribution of Landslides in Nepal, In: Eslamina, S. and Eslamina, F., (Eds.) Handbook of Disaster Risk Reduction for Resilience, Springer, 2021, pp. 453-471.

[47] [47] Dixit A., Karki M. and Shukla A. Vulnerability and Impacts Assessment for Adaptation Planning in Panchase Mountain Ecological Region, Nepal. Government of Nepal, United Nations Environment Programme, United Nations Development Programme, International Union for Conservation of Nature, German Federal Ministry for the Environment, Nature Conservation, Building and Nuclear Safety and Institute for Social and Environmental Transition-Nepal, 2015.

[48] IPCC- Intergovernmental Panel on Climate Change. Synthesis Report. Contribution of Working Groups I, II and III to the Fifth Assessment Report of the Intergovernmental Panel on Climate Change, Geneva, Switzerland, 2014, pp 151.

[49] Caine N. The rainfall intensity-duration control of shallow landslides and debris flows. Geogr. Ann. Vol. 62A, No.1-2, 23-27, 1980.

[50] Basnet P., Balla M. K. and Pradhan B. M. Landslide hazard zonation, mapping and investigation of triggering factors in Phewa lake watershed, Nepal. Banko Janakari, Vol. 22, No. 2, 43-52, 2013. DOI: https://doi.org/10.3126/banko.v22i2. 9198

[51] Devkota S., Shakya N.M., Sudmeier K., McAdoo B.G. and Jaboyedoff M. Predicting soil depth to bedrock in an anthropogenic landscape: a case study of Phewa Watershed in Panchase region of Central-Western Hills, Nepal. Journal of Nepal Geological Society, Vol. 55 (Sp. Issue), pp. 173-182, 2018.

[52] Jaboyedoff M., Michoud C., Derron M., Voumard J., Leibundgut G., Sudmeier-Rieux K., Michoud C., Nadim F. and Leroi E. Human-Induced Landslides: Toward the analysis of anthropogenic changes of the slope environment. Landslides and Engineered Slopes. Experience, Theory and Practice. pp. 217-232, 2016. https://doi.org/10.1201/b215 20-20

[53] Leibundgut G., Sudmeier-Rieux K., Devkota S., Jaboyedoff M., Derron M.-H., Penna I. and Nguyen L. Rural earthen roads impact assessment in Phewa watershed, Western region, Nepal. Geoenvironmental Disasters, Vol. 3, No. 13, 2016. https://doi.org/10.1186/s40677-016-0047-8 
[54] Fort M., Cossart E., Deline P., Dzikowski M., Nicoud G., Ravanel L., Schoeneich P., Wassmer P. (2009). Geomorphic impacts of large and rapid mass movements; a review. Géomorphologie: relief, processus, environnement, $1,59-74$.

[55] Bista J.B. and Basnet K. Assessment of Land Use Land Cover Change Impact on Soil Loss from Phewa Lake Watershed, Pokhara, Nepal. Proceedings of $9^{\text {th }}$ IOE Graduate Conference, Peer Reviewed, 9, 2021. http://conference.ioe.edu.np/ioegc9/papers/ioegc-9-036-90 065.pdf

[56] CBS. Environment Statistics of Nepal 2019. Government of Nepal, National Planning Commision, Central Bureau of Statitistics, Ramshah Path, Thapathali, Kathmandu, 2019.

[57] Fleming W.M. Phewa Tal Catchment Management Program: benefits and costs of forestry and soil conservation in Nepal. In S.H. Lawrence, ed. Forest watershed development and conservation in Asia and the Pacific, Boulder, Colorado, USA, Westview Press, pp. 217-288, 1983.

[58] Pokharel S. Lessons from Nepal on Developing a Strategic Plan for the Integrated Lake Basin Management Conservation of Phewa Lake of Pokhara, Nepal. Sigha University and ILEC, 2009.

[59] Sthapit K.M., and Baila M.K. Sediment Monitoring of Phewa Lake. Watershed Management and Environmental Science, Kathmandu: Institute of Forestry, 1998.

[60] Laban P. Landslide occurrence in Nepal. Kathmandu: Integrated watershed management torrent control and Land use development project, Ministry of Forest, Department of Soil and Water Conservation, 1979.

[61] JICA/SILT. The Development study on the environmental conservation of Phewa Lake. Kathmandu: Silt Consultants (P) Ltd, 2002.

[62] Watson C.S., Jeffrey S.K., Regmi D., Rupper S., Maurer J.M. and Karki A. Shrinkage of Nepal's Second Largest Lake (Phewa Tal) Due to Watershed Degradation and Increased Sediment Influx. Remote Sensing, Vol. 11, No. 4, P. 444, 2019. https://doi.org/10.3390/rs1 1040444

[63] MFSC. Nepal National Biodiversity Strategy and Action Plan 2014-2020. Ministry of Forest and Soil Conservation (MFSC), Kathmandu, Nepal, 2014a.

[64] Shrestha B.B. In: P.K. Jha, M. Siwakoti and S. Rajbhandary (Eds) Invasive Alien Plant Species in Nepal. Frontiers of Botany, Publisher: Central Department of Botany, Tribhuvan University, Kirtipur, Kathmandu, pp. 269-284, 2016.

[65] Siwakoti, M. Threats and opportunity of invasive alien plant species in wetland conservation of Nepal. In: Proceedings of International Wetland Symposium, November 7-9, 2012, Pokhara, Nepal. Ministry of Forest and Soil Conservation/Conservation and Sustainable Use of Wetlands in Nepal. pp. 66-72, 2012.

[66] Sukhorukov, A.P. Erigeron annuus (Compositae)- a new record for the flora of Nepal. Newsletter of Himalayan Botany No. 49 (December): 15-16, 2014.

[67] Stainton J.D.A. Forests of Nepal. John Murray, London, 1972.
[68] Bajracharya D.M., Subedi A. and Shrestha K.K. Eria pokharensis sp. Nov. (Orchidaceae); A new species from Nepal Himalaya. J Orchid Soc India, 17(1-2): 1-4, 2003.

[69] Subedi A, Chaudhary, RP, Vermeulen JJ, Gravendeel B. A new species of Panisea (Orchidaceae) from central Nepal. Nordic Journal of Botany 29: 361-365, 2011.

[70] Raskoti B.B. A new species of Gastrochilus and new records for the orchids of Nepal. Phytotaxa 233(3): 179$184,2015$.

[71] Raskoti B.B. and Kurzweil H. Odontochilus nandae (Orchidaceae; Cranichidae; Goodyerinae), a new species from Nepal. Phytotaxa 233(3): 293-297, 2015.

[72] Pathak H.N., Bhuju D.R., Shrestha B.B. and Ranjitkar S. Impacts of invasive alien plants on ecosystem services of Ramsar lake cluster in middle mountain Nepal. Global Ecology and Conservation. Vol. 27, e01597, 2021. https://doi.org/10.1016/j.gecco.2021.e01597

[73] Acharya S. Land use and land cover changes in the catchments impact the ecosystem in Phewa, Begnas, and Rupa lakes, Nepal. Journal of Nepal Geological Society, Vol. 60, pp. 195-205, 2020. https://doi.org/10.3126/jngs.v6 $0 \mathrm{i} 0.31267$

[74] MoFE. Integrated Lake Basin Management Plan of Lake Cluster of Pokhara Valley, Nepal. 2018-2023. Ministry of Forests and Environment, Kathmandu, Nepal, 2018b.

[75] PSPL/IUCN. Impact Assessment of Invasive Plant species in Selected Ecosystems of Bhadaure Tamagi VDC, Kaski. IUCN Nepal, Kupondole, Lalitpur, Nepal, 2013.

[76] Wilson J.R., Rees M., Holst N., Thomas M.B. and Hill G. Water hyacinth population dynamics. In: M.H. Julien, M.P. Hill, T.D. Center, and D. Jianqing, (Eds.), Biological and integrated control of water hyacinth, Eichhornia crassipes. Proceedings of the 2nd Meeting of the Global Working Group for the Biological and Integrated Control of Water hyacinth, Beijing, China, 9-12 October 2000. ACIAR Proceedings No. 102. pp. 96-104, 2001

[77] Malik A. Environmental challenge vis a vis opportunity: The case of water hyacinth. Environment International, Vol. 33, pp. 122-138, 2007.

[78] Gupta P., Roy S. and Mahindrakar A.B. Treatment of water using water hyacinth, water lettuce and vetiver grass - a review. Res. Environ, 2, 202-215, 2012.

[79] Kafle B., Mani B., Dahal B. M., Chhatra M., Sharma C., Kafle K., Gurung S., Raut N. and Manandhar S. Physicochemical Characterization of Water Samples from Lake Phewa and Kulekhani Reservoir, Nepal. A conference paper, NRACC, 2020.

[80] Shad N., Zhang L., Shah G.M., Haifu F., Ilyas M., Ali A. and Khan S.A. Plant Invasion and $\mathrm{N}_{2} \mathrm{O}$ Emission in Forest Ecosystems. In: Ling Zhang (Ed), Advances in Forest Management under Global Change, 2020. DOI: 10.5772/intechopen.92239

[81] Acharya K., Tiwari K. R., Sharma S., Upadhyaya C. P., Timilsina Y. P. and Jha R. Monsoon and post-monsoon evaluation of water quality of Phewa Lake in Pokhara, Midwestern Nepal. International Journal of Ecology and Conservation, Vol. 3, 2012. 
[82] Wester P., Mishra A., Mukherji A., Shrestha A. B. (Eds). The Hindu Kush Himalaya Assessment-Mountains, Climate Change, Sustainability and People. Springer Nature Switzerland AG, Cham, 2019.

[83] Bishwakarma K., Pant R. R., Pal K. B., Ghimire A., Thapa L. B., Saud P., Joshi S. and Panthi, K. P. Water quality and land use/cover changes in the Phewa Watershed, Gandaki Province, Nepal. Nepal Journal of Environmental Science, Vol. 7, 31-39, 2019. https://doi.org/10.3126/njes.v7i0.344 73

[84] Johnson M.P. and Bedell T. Watershed function. Agriculture and Natural Resources, Vol. 10, No. 1, University of California, pp. 1-4, 2002.

[85] EPA. Addressing Water Quality Challenges Using a Watershed Approach. Environmental Protection Agency 1200 Pennsylvania Avenue, N.W. Mail Code: 4503T, Washington, DC 20460, 2021.

[86] Lake Erie Lakewide Management Plan /U.S. Environmental Protection Agency and Environment Canada, Appendixes $E$ and $F$ : Environment Canada, Ontario Region, Burlington, Ontario, Canada, variously paginated, 2000 .

[87] NPC. The Tenth Five-Year Plan, 2002-2007, National Planning Commission (NPC), Kathmandu, Government of Nepal, 2003.

[88] JICA. Interim Report on the Development Study on the Environment Preservation of Phewa Lake in Pokhara, Nepal. Tripureswor, Kathmandu, Nepal, 2001, pp. 9-124

[89] Sharma P.N., Mishra B., Dent F.J., Achet S.H., Escano J., Gamage H. and Gunawardhana E.R.N. Key elements of participatory processes for integrated watershed management. In P.N. Sharma (Ed), Participatory process for integrated watershed management. Field Doc. No. 7, PMWTA/FAO, Kathmandu, FAO, 1997.

[90] Pimentel D., Berger B., Filiberto D., Newton M., Wolfe B., Karabinakis E., Clark S., Poon E., Abbett E. and Nandaopal S. Water Resources, Agriculture, and the Environment. Environmental Biology Report 04-1. Ithaca (NY): New York State College of Agriculture and Life Sciences, Cornell University, 2004.

[91] Bathurst J.J., Bovolo C.I. and Cisneros F. Modelling the Effect of Forest Cover on Shallow Landslides at the River Basin Scale. Ecological Engineering, Vol. 36, 317-327, 2009.

[92] Gerrard J. and Gardner R. Relationships between Landsliding and Land Use in the Likhu Khola Drainage Basin, Middle Hills, Nepal. Mountain Research and Development, Vol. 22, No. 1, 48-55, 2002.

[93] Schmidt K.M. et al. The Variability of Root Cohesion as an Influence on Shallow Landslide Susceptibility in the Oregon Coast Range. Canadian Geotechnical Journal, Vol. 38, No. 5, pp. 995-1024, 2001.

[94] Vanoost K., Govers G. and Desmet P. Evaluating the Effect of Changes in Landscape Structure on Soil Erosion by Water and Tillage. Landscape Ecology, Vol. 15, No. 6, pp. 577-589, 2008.

[95] Eshghizadeh M., Talebi A., Dastorani M.T. and Azimzadeh H.R. Effect of Natural Land Covers on Runoff and Soil
Loss at the Hill-Slope Scale. Global Journal of Environmental Science Management, Vol. 2, No. 2, 125-134, 2015.

[96] Igwe P.U., Ezeukwu J.C., Edoka N.E., Ejie O.C. and Ifi G.I. A Review of Vegetation Cover as a Natural Factor to Soil Erosion. International Journal of Rural Development, Environment and Health Research, Vol. 1, No. 4, pp. 21-28, 2017. https://doi.org/10.22161/ijreh.1.4.4

[97] Collison A.J.C, Anderson M.G. and Lioyd D.M. Impact of Vegetation on Slope Stability in a Humid Tropical Environment: A Modeling Approach. Proceedings of the ICE-Water Maritime and Energy 112 (2), 168-75, 1995. http://www.icevirtuallibrary.com/content/article/10.1680/i wtme.1995.27662.

[98] Vanacker V., Vanderschaeghe M, Govers G., Willems E., Poesen J., Deckers J. and Bievre B.De. Linking Hydrological, Infinite Slope Stability and Land-Use Change Models through GIS for Assessing the Impact of Deforestation on Slope Stability in High Andean Watersheds. Geomorphology, Vol. 52, No. (3-4), pp. 299 315, 2003. https://doi.org/10.1016/S0169-555X(02)002635.

[99] Hasnawir, Tetsuya K., Laura S.C. and Andang S.S. Root Strength of Understory Vegetation for Erosion Control on Forest Slopes of Kerala Watershed, Indonesia. Proceedings of the 2nd Makassar International Conference on Civil Engineering (MICCE 2015). Makassar, Indonesia, 2015.

[100] Molina A. Govers, G., Cisneros, F., and Vanacker, V. Vegetation and topographic controls on sediment deposition and storage on gully beds in a degraded mountain area. Earth Surface Processes and Landforms, Vol. 34, No. 6, 755-767, 2009. doi:10.1002/esp. 1747.

[101] Rehman O. Ur, Rashid M., Kausar R., Alvi S. and Hussain R. Slope Gradient and Vegetation Cover Effects on the Runoff and Sediment Yield in Hillslope Agriculture. Turkish Journal of Agriculture- Food Science and Technology (TURJAF), Vol. 6, No. 3, 2015. https://doi.org/10.24925/turjaf.v3i6.478-483.292

[102] Sastry T.C.S. and Kavathekar K.Y. (Ed.). Plants for Reclamation of Wastelands. Publication and Information Directorate, Council of Scientific \& Industrial Research, Hillside Road, New Delhi, India, 1990.

[103] Norris J.E., Stokes A., Mickovski S.B., Cammeraat E., Beek R.V., Nicoll B.C. and Achim A. Slope Stability and Erosion Control: Ecotechnological Solutions (Eds.). Springer Science + Business Media B.V, 2015.

[104] Mitchell S.J. Wind as a natural disturbance agent in forests: a synthesis. Forestry: An International Journal of Forest Research, Vol. 86, No. 2, pp. 147-157, 2013. https://doi.org/10.1093/forestry/cps058

[105] Istanbulluoglu E. and Bras R.L. Vegetation-modulated landscape evolution: Effects of vegetation on landscape processes, drainage density, and topography. Journal of Geophysical Research, Vol. 110, F02012, 2005. https://doi.org/10.1029/2004JF000249

[106] Devkota B.D., Paudel P., Omura H., Kubota T. and Morita, K. Uses of Vegetative Measures for Erosion Mitigation in Mid Hill Areas of Nepal. Kyushu Journal of Forest Research, Vol. 59, No. 3, 265-268, 2006.

[107] Bo M.W., Fabius M. and Fabius K. Impact of Global 
Warming on Stability of Natural Slopes". In J. Locat, D. Perret, D. Turmel, D. Demers and S. Leroueil (Eds), Proceedings of the 4th Canadian Conference on Geohazards: From Causes to Management. Quebec: Presse de l'Université Laval, 2008.

[108] Radocevich S.R., Prather T., Ghersa C.M. and Lass L. Implementing science based invasive plant management. In: Inderjit (Ed.), Management of Invasive Weeds. Springer Science + Business Media B.V., pp. 345-359, 2009.

[109] Anonymous. Water hyacinth generating income. The Himalayan Times; 2015a. URL: http://thehimalayantimes.c om/nepal/water-hyacinth-generating-income/[Accessed on Oct 9, 2015].

[110] Mooney H., Larigauderie A., Cesario M., Elmquist T., Hoegh-Guldberg O., Lavorel S., Mace G.M., Palmer M.,
Scholes R. and Yahara T. Biodiversity, climate change, and ecosystem services. Current Opinion in Environmental Sustainability, Vol. 1, No. 1, pp. 46-54, 2009.

[111] MFSC. Nepal Biodiversity Strategy. Ministry of Forest and Soil Conservation (MFSC), Kathmandu, Nepal, 2002.

[112] Nguyen T.H.T., Boets P., Lock K., Ambarita M.N.D., Forio M.A.E., Sasha P., Dominguez-Granda L.E., Hoang T.H.T., Everaert G. and Goethals P.L.M. Habitat suitability of the invasive water hyacinth and its relation to water quality and macroinvertebrate diversity in a tropical reservoir, Limnologica, Vol. 52, pp. 67-74, 2015. https://doi.org/10.1 016/j.limno.2015.03.006.

[113] Jafari N.G. and Trivedy R.K. Environmental pollution control by using phytoremediation technology. Pollution Research, Vol. 24, No. 4, pp. 875-884, 2005. 